\title{
Epidemiology of headache and migraine in women
}

\author{
W. E. WATERS' AND P. J. O'CONNOR
From the Medical Research Council Epidemiology Unit (South Wales), Cardiff, and the Central Medica莡 \\ Establishment (R.A.F.), London
}

SUMMARY During a survey of a defined community, 2,933 women aged 20 to 64 years were asked standard questions about headaches. Overall, $78.7 \%$ had headaches during the year immediately preceding the survey and this proportion decreased significantly with age. Random samples of sub $\frac{\mathcal{N}}{\widetilde{\Phi}}$ groups with unilateral headaches, headaches preceded by a warning, and headaches accompanied? by nausea were examined clinically. From these clinical diagnoses the prevalence of women withi migraine during the previous year was estimated as $19 \%$. Nearly half of those diagnosed as havings migraine had never consulted a doctor because of headaches. Women with migraine and non $=$ migraincus headaches kept diaries of all headaches and data are presented for the time and day of onset, severity, duration and relation of menstruation for both types of headache.

保

Headache is one of the commonest symptoms but little is known about its epidemiology in the general population. The majority of headaches are clinically classified into the two groups-muscle-contraction ('psychogenic' or 'tension') headaches, and migraine. Migraine is described as an episodic headache which is commonly unilateral, usually preceded by premonitory symptoms such as neurological or mood disturbances, and frequently accompanied by nausea and sometimes vomiting. The results of surveys indicate that three features characteristic of migraine (unilateral distribution of headache, warning before headache, accompanying nausea) are surprisingly frequent in the general population (Waters, 1970). The use of a standard questionnaire in the surveys leads to considerable difficulties in differentiating clearly between migraine and other headaches. This difficulty is at least in part due to the problem of defining migraine precisely. Most definitions are really descriptions of the features of a typical attack -for example, Gowers, 1886-88; Ad Hoc Committee on Classification of Headache, 1962; World Federation of Neurology's Research Group on Migraine and Headache, 1969). The prevalence of migraine will, of course, depend on the diagnostic criteria.

Although vascular changes have been described during migraine attacks (Wolff, 1963) and even between attacks in some migraine sufferers (Appenzeller, Davison, and Marshall, 1963), migraine is a disorder of function and it has no known morbid anatomy (Walshe, 1969). Migraine is therefore essen-

'Present address: Faculty of Medicine, The University, Highfield, Southampton SO9 5NH. tially a clinical diagnosis and to examine its epi demiology it is theoretically desirable, but practica $\$ \dot{y}$ difficult, for a neurologist to examine a large rand $\$$ no sample of the general population. As a compromise? some initial screening procedure can be carried entin the general population and smaller subgroup examined clinically. This paper describes such investigation where a community survey was dônę using a standard questionnaire and random sampeses of subgroups were examined in more detail.

\section{METHODS}

INITIAL SCREENING During a community survey in the Rhondda Fach (Glamorgan), women between the ages of 20 and 64 years living in a defined area were askef standard questions about headaches during the previous year and whether or not they were one-sided, preceded by a warning, or accompanied by nausea. Severity was assessed by asking each subject with headaches to choose one of seven statements, presented on a printed card $\overline{\bar{S}}$ which most accurately described her severe headaches? The statements represented a scale of increasing severity ranging from 'My headaches are very mild' (grade 1) to 'My headaches are almost unbearable' (grade 7).

Random samples of women, from various subgroups identified by the questionnaire, were later visited in thei $\overline{6}$ homes and a more detailed headache questionnaire com pleted by one observer who was familiar with the ques $\frac{D}{8}$ tionnaire. This questionnaire elicited a variety of details. about headaches including those of relevance to migraine and also contained nine questions derived from the Cornell Medical Index Health Questionnaire which haff been used previously in community studies of psychoN neurosis (Rawnsley, 1966). 
CLINICAL INTERVIEW Random samples of women from subgroups with all combinations of the three features of migraine (unilateral headache, warning before headache, accompanying nausea) were visited in their homes for a clinical assessment of their headaches (P.J. O'C.). The method of questioning, and the examination of these subjects, was that used in normal clinical practice. Each was diagnosed as having either migraine or non-migrainous headache or placed in a third category if the diagnosis was uncertain. A clinical assessment of psychoneurotic predisposition was made at the same time. During the clinical interview the clinician was not aware of how the subjects had been selected nor of their replies to the questionnaires.

DIARIES All 117 women who had a clinical assessment of their headaches were asked to keep diaries of their headaches during the subsequent six months. Information was collected regarding the time and day of onset, the severity and duration, and whether or not the headaches were one-sided, preceded by a warning, or accompanied by nausea. The dates of menstrual periods were also obtained. Each woman was visited at least once each month by a nurse to check that the diary forms were being maintained satisfactorily.

\section{RESULTS}

PREVAlENCE OF HEADACHE AND MIGRAINe Two thousand nine hundred and thirty-three women, over $86 \%$ of those between 20 and 64 years living in the defined area, were seen during the initial screening survey. Table 1 shows that the proportion of women with a headache during the previous year decreases significantly with age $(P<0.001)$. Of those with headaches there is no evidence of an association between age and severity as judged on the seven point severity scale (Table 2). The proportion of women with unilateral headaches and aura is not related to age and, although the lower proportion with nausea in the 55 to 64 year age group is statistically significant, the actual difference is small (Table 3). Table 4 shows that the prevalence of unilateral

TABLE 1

NUMBERS OF WOMEN OF VARIOUS AGES, SEEN IN COMMUNITY SURVEY, WHO HAD HAD HEADACHE DURING PREVIOUS YEAR

\begin{tabular}{crrrrrr}
\hline $\begin{array}{c}\text { Age group } \\
(y r)\end{array}$ & \multicolumn{2}{c}{ Headache } & \multicolumn{2}{c}{ No headache } & \multicolumn{2}{c}{ Total } \\
$($ no. $)$ & $(\%)$ & $($ no. $)$ & $(\%)$ & $($ no. $)$ & $(\%)$ \\
\hline $20-34$ & 805 & $82 \cdot 9$ & 166 & $17 \cdot 1$ & 971 & 100 \\
$35-54$ & 1112 & $80 \cdot 1$ & 277 & $19 \cdot 9$ & 1389 & 100 \\
$55-64$ & 392 & $68 \cdot 4$ & 181 & $31 \cdot 6$ & 573 & 100 \\
All ages & 2309 & $78 \cdot 7$ & 624 & $21 \cdot 3$ & 2933 & 100 \\
\hline
\end{tabular}

$\chi^{2}=48.0$; D.F. $2 ; \mathrm{P}<0.001$ significant.

TABLE 2

ASSOCIATION BETWEEN AGE AND SEVERITY OF HEADACHE

\begin{tabular}{|c|c|c|c|c|c|c|c|c|}
\hline \multirow{2}{*}{$\begin{array}{c}\text { Age group } \\
(y r)\end{array}$} & \multicolumn{7}{|c|}{ Severity of headache* } & \multirow[t]{2}{*}{ Total } \\
\hline & $I$ & 2 & 3 & 4 & 5 & 6 & 7 & \\
\hline 20-34 (no.) & 144 & 186 & 170 & 191 & 141 & 17 & 56 & 805 \\
\hline$(\%)$ & 18 & 23 & 21 & 24 & 5 & 2 & 7 & 100 \\
\hline $35-54$ (no.) & 172 & 249 & 239 & 275 & 62 & 28 & 87 & 1112 \\
\hline$(\%)$ & 15 & 22 & 21 & 25 & 6 & 3 & 8 & 100 \\
\hline $55-64$ (no.) & 75 & 95 & 104 & 69 & 19 & 11 & 19 & 392 \\
\hline$(\%)$ & 19 & 24 & 27 & 18 & 5 & 3 & 5 & 100 \\
\hline Total (no.) & 391 & 530 & 513 & 535 & 122 & 556 & 162 & 2309 \\
\hline$(\%)$ & 17 & 23 & 22 & 23 & 5 & 2 & 7 & 100 \\
\hline
\end{tabular}

*See text.

$\chi^{2}=18.5 ;$ D.F. $=12 ; 0.1<\mathbf{P}<0.25$. Not significant.

TABLE 3

ASSOCIATION BETWEEN AGE AND THREE FEATURES OF HEADACHE CHARACTERISTIC OF MIGRAINE

\begin{tabular}{ccccccccc}
\hline $\begin{array}{c}\text { Age group } \\
(\text { yr })\end{array}$ & $\begin{array}{c}\text { With } \\
\text { headache }\end{array}$ & $\begin{array}{c}\text { Headache } \\
\text { with } \\
\text { unilateral } \\
\text { distribution }\end{array}$ & $\begin{array}{c}\text { Headache } \\
\text { with } \\
\text { warning }\end{array}$ & $\begin{array}{c}\text { Headache } \\
\text { with } \\
\text { nausea }\end{array}$ \\
& $($ no. $)$ & $(\%)$ & $($ no. $)$ & $(\%)$ & $($ no. $)$ & $(\%)$ & $($ no. $)$ & $(\%)$ \\
\hline $20-34$ & 805 & 100 & 350 & 43 & 192 & 24 & 300 & 37 \\
$35-54$ & 1112 & 100 & 441 & 40 & 282 & 25 & 427 & 38 \\
$55-64$ & 392 & 100 & 151 & 39 & 79 & 20 & 123 & 31 \\
Total & 2309 & 100 & 942 & 40 & 553 & 23 & 850 & 37 \\
Significance & & - & $0.1<\mathrm{P}<0.25$ & $0.1<\mathrm{P}<0.25$ & $0.025<\mathrm{P}<0.05$
\end{tabular}

TABLE 4

NUMBER OF WOMEN WITH THREE FEATURES CHARACTERISTIC OF MIGRAINE IN RELATION TO SEVERITY OF HEADACHE

\begin{tabular}{|c|c|c|c|c|c|c|c|c|c|}
\hline & \multicolumn{7}{|c|}{ Severity of headache* } & \multirow{2}{*}{ Total } & \multirow{2}{*}{ Significance } \\
\hline & 1 & 2 & 3 & 4 & 5 & 6 & 7 & & \\
\hline Women (no.) & 391 & 530 & 513 & 535 & 122 & 56 & 162 & 2309 & \\
\hline $\begin{array}{l}\text { With unilateral headache } \\
(\text { no.) } \\
(\%)\end{array}$ & $\begin{array}{r}103 \\
26\end{array}$ & $\begin{array}{r}176 \\
33\end{array}$ & $\begin{array}{r}215 \\
42\end{array}$ & $\begin{array}{r}272 \\
51\end{array}$ & $\begin{array}{l}59 \\
48\end{array}$ & $\begin{array}{l}28 \\
50\end{array}$ & $\begin{array}{l}89 \\
55\end{array}$ & $\begin{array}{r}942 \\
41\end{array}$ & $P<0.001$ \\
\hline $\begin{array}{l}\text { With warning } \\
(\text { no.) } \\
(\%)\end{array}$ & $\begin{array}{r}31 \\
8\end{array}$ & $\begin{array}{l}58 \\
11\end{array}$ & $\begin{array}{r}111 \\
22\end{array}$ & $\begin{array}{r}187 \\
35\end{array}$ & $\begin{array}{l}41 \\
34\end{array}$ & $\begin{array}{l}26 \\
46\end{array}$ & $\begin{array}{l}99 \\
61\end{array}$ & $\begin{array}{r}553 \\
24\end{array}$ & $P<0.001$ \\
\hline $\begin{array}{l}\text { With nausea } \\
\text { (no.) } \\
(\%)\end{array}$ & $\begin{array}{l}39 \\
10\end{array}$ & $\begin{array}{l}90 \\
17\end{array}$ & $\begin{array}{r}174 \\
34\end{array}$ & $\begin{array}{r}308 \\
58\end{array}$ & $\begin{array}{l}69 \\
57\end{array}$ & $\begin{array}{l}43 \\
77\end{array}$ & $\begin{array}{r}127 \\
78\end{array}$ & $\begin{array}{r}850 \\
37\end{array}$ & $P<0.001$ \\
\hline
\end{tabular}

See text.

4 
headaches, headaches with warning, and headaches accompanied by nausea all increase significantly with increasing severity of headache.

Random samples of women from various subgroups of the total population, defined by combinations of symptoms, were examined clinically. Table 5

\section{TABLE 5}

NUMBER OF WOMEN AGED 20 TO 64 YEARS WITH VARIOUS PATTERNS OF HEADACHE AND PROPORTIONS IN EACH SUBGROUP DIAGNOSED AS MIGRAINE IN CLINICAL INTERVIEW

\begin{tabular}{|c|c|c|c|c|}
\hline Pattern of headache & $\begin{array}{l}\text { Women } \\
\text { (no.) }\end{array}$ & $\begin{array}{l}\text { Interviewed } \\
\text { clinically } \\
\text { (random } \\
\text { sample) } \\
\text { (no.) }\end{array}$ & $\begin{array}{c}\text { Diagnosed } \\
\text { as migraine } \\
\text { in random } \\
\text { sample } \\
(\%)\end{array}$ & $\begin{array}{c}\text { Calculated } \\
\text { no. with } \\
\text { migraine }\end{array}$ \\
\hline None & 624 & 0 & 一 & 一 \\
\hline Headache only & 854 & 3 & $\mathbf{0}$ & - \\
\hline Unilateral & 413 & 17 & $11 \cdot 8$ & $48 \cdot 7$ \\
\hline With warning & 100 & 4 & 50.0 & $50 \cdot 0$ \\
\hline $\begin{array}{l}\text { With nausea } \\
\text { Unilateral with }\end{array}$ & 251 & 17 & $23 \cdot 5$ & $59 \cdot 0$ \\
\hline warning & 92 & 12 & $58 \cdot 3$ & 53.6 \\
\hline $\begin{array}{l}\text { Unilateral with } \\
\text { nausea }\end{array}$ & 238 & 22 & $31 \cdot 8$ & $75 \cdot 7$ \\
\hline $\begin{array}{l}\text { With warning and } \\
\text { nausea }\end{array}$ & 162 & 10 & $60 \cdot 0$ & $97 \cdot 2$ \\
\hline warning and nausea & 199 & 32 & $87 \cdot 5$ & $174 \cdot 1$ \\
\hline Total & 2933 & 117 & - & $558 \cdot 3$ \\
\hline
\end{tabular}

shows the proportion in each subgroup with a clinical diagnosis of migraine. Knowing the size of each subgroup and the proportion with migraine the overall prevalence of migraine in the community is estimated as 558 out of 2,933 women aged 20 to 64 years $(19 \%)$. Of those diagnosed clinically as migraine only 13 out of $56(23 \%)$ had consulted a doctor about their headaches during the previous year but $26(46 \%)$ had not done so at any time.

SEVERITY OF HEADACHE AND PSYCHONEUROSIS The severity of the headache assessed on the seven point scale is significantly greater in the migraine group than in those with non-migrainous headaches (Table 6 ), although there is a considerable overlap between the two groups.

There is good agreement between the questionnaire and the clinical assessment of psychoneurosis. The psychoneurotic predisposition was assessed clinically as absent, slight, moderate, or severe and the corresponding mean scores derived from the nine questions are $2 \cdot 4,2 \cdot 7,4 \cdot 7$, and $4 \cdot 9$. There is no significant difference $(0.5<\mathrm{P}<0.7)$ in the psychoneurotic grades of women with migraine and nonmigrainous headache (Table 7) but where there was some doubt in the diagnosis the psychoneurotic grades tend to be higher.

DIARIES All 117 women who were examined clinic-
TABLE 6

SEVERITY OF HEADACHE IN WOMEN DIAGNOSED CLINICALLD AS HAVING MIGRAINE AND NON-MIGRAINOUS HEADACHES్

\begin{tabular}{|c|c|c|c|c|c|c|c|c|c|}
\hline \multirow[t]{2}{*}{ Clinical diagnosis } & \multicolumn{7}{|c|}{ Severity of headache* } & \multirow[t]{2}{*}{ Mean } & \multirow[t]{2}{*}{ TotaE } \\
\hline & 1 & 2 & 3 & 4 & 5 & 6 & 7 & & \\
\hline $\begin{array}{l}\text { Migraine } \\
\text { (no.) } \\
(\%)\end{array}$ & $\begin{array}{l}1 \\
2\end{array}$ & $\begin{array}{l}3 \\
5\end{array}$ & $\begin{array}{r}6 \\
11\end{array}$ & $\begin{array}{l}20 \\
36\end{array}$ & $\begin{array}{r}8 \\
14\end{array}$ & $\begin{array}{r}8 \\
14\end{array}$ & $\begin{array}{l}10 \\
18\end{array}$ & $4 \cdot 7$ & $\begin{array}{r}56 \\
100\end{array}$ \\
\hline $\begin{array}{l}\text { Non-migrainous } \\
\text { headache }\end{array}$ & & & & & & & & & \\
\hline $\begin{array}{l}\text { (no.) } \\
(\%)\end{array}$ & $\begin{array}{r}7 \\
16\end{array}$ & $\begin{array}{r}8 \\
18\end{array}$ & $\begin{array}{r}6 \\
14\end{array}$ & $\begin{array}{l}13 \\
29\end{array}$ & $\begin{array}{r}6 \\
14\end{array}$ & $\frac{\mathbf{0}}{-}$ & $\begin{array}{l}4 \\
9\end{array}$ & $3 \cdot 6$ & $\begin{array}{c}44 \\
100\end{array}$ \\
\hline
\end{tabular}

*See text.

$\chi^{2}=15.7 ;$ D.F. $=4 ; \mathrm{P}<0.005$ Significant.

TABLE 7

ASSOCIATION BETWEEN TYPE OF HEADACHE AND AN ASSESS MENT OF PSYCHONEUROSIS

\begin{tabular}{|c|c|c|c|c|c|}
\hline \multirow[t]{2}{*}{ Clinical diagnosis } & \multicolumn{4}{|c|}{ Psychoneurotic score* } & \multirow{2}{*}{$\begin{array}{l}\text { Mean } \\
\text { score }\end{array}$} \\
\hline & (no.) & $0-2$ & $3-5$ & $6-9$ & \\
\hline Migraine & 56 & 20 & 22 & 14 & 3.7 \\
\hline Doubtful & 17 & 6 & 6 & 5 & $4 \cdot 2$ \\
\hline Not migraine & 44 & 18 & 16 & 10 & 3.5 \\
\hline
\end{tabular}

ally made some attempt to keep diaries of th] headaches but the degree of cooperation extremely variable. Migrainous and non-migrainow headaches are analysed by time and day of onseg and by the severity and duration of the headaches (Table 8). The classification into migraine and no migrainous headache depended on the previous clinical diagnosis and in addition all the 289 migraineo attacks analysed in Table 8 had at least two of the features; unilateral headache, preceding warning, accompanying nausea. None of the 243 non- $\frac{\circ}{\circ}$ migrainous headaches by definition had any of these 2 three features.

The incidence of both migraine and non-migrain- 3 ous headaches is significantly higher during the menstrual period. There is evidence that progres-? sively fewer episodes were recorded during the six months that diaries were kept and there was selective? drop-out. Only the women who kept diaries for: more than a complete cycle are shown. Analyses based on first and second cycles test the reproduc- 8 ibility and analyses of incidences in the non-menstruating portion of the first cycle are compared with 0 those in the menstrual period of the second cycle because of the temporal effect (Table 9). The statistical significances are based on the $\chi^{2}$-heterogeneity test with modifications to adjust for stratification or (Armitage, 1966), the strata in this case being in- N dividual women. Thus the incidence of migraine $\underset{\mathrm{N}}{\mathrm{N}}$ attacks is about twice as frequent, and non-migrain- 
ous headache more than twice as frequent, during menstruation.

Analysis of all the diaries showed that 84 migraine attacks occurred in the seven days after menstruation and only 52 in the seven days before menstruation. Even allowing for the temporal and selective effect of drop-out, these figures contradict the usual hypothesis that migraine is common immediately before menstruation.

\section{DISCUSSION}

There are little published data on the prevalence of migraine in women. Most figures are general im-

TABLE 8

COMPARISON OF TIME AND DAY OF ONSET, SEVERITY AND DURATION OF HEADACHE IN 289 MIGRAINE ATTACKS AND 243 NON-MIGRAINOUS HEADACHES

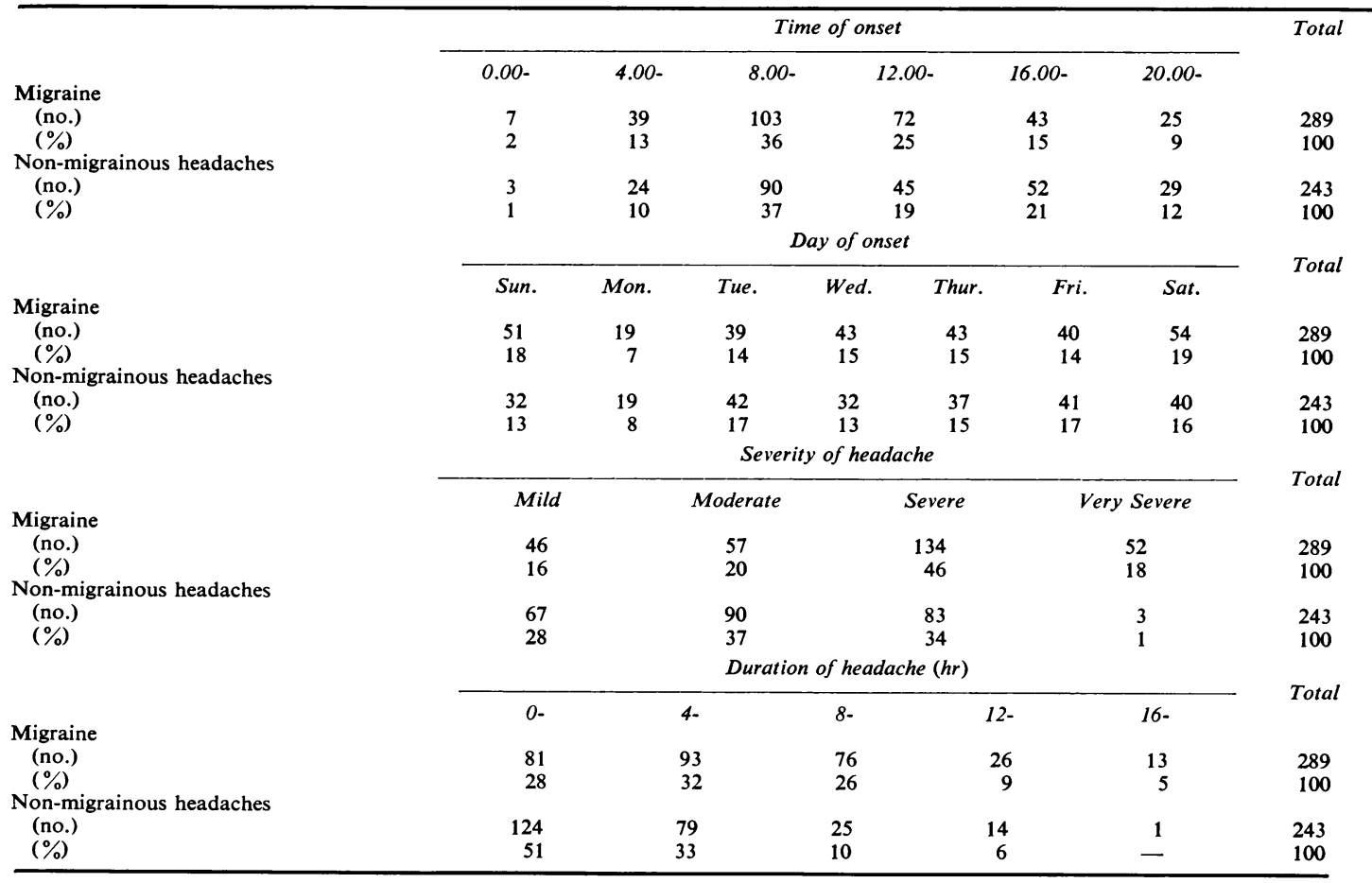

TABLE 9

ASSOCIATION BETWEEN MIGRAINE AND NON-MIGRAINOUS HEADACHE AND MENSTRUATION IN 41 WOMEN CLINICALLY DIAGNOSED AS MIGRAINE AND 14 DIAGNOSED AS NON-MIGRAINOUS HEADACHF.

\begin{tabular}{|c|c|c|c|c|c|c|c|c|}
\hline & & \multicolumn{3}{|c|}{ During menstrual period } & \multicolumn{3}{|c|}{ Between menstrual period } & \multirow[t]{3}{*}{ Probability } \\
\hline & & \multirow{2}{*}{$\begin{array}{l}\text { Days } \\
\text { (no.) }\end{array}$} & \multicolumn{2}{|c|}{ Days with attack } & \multirow{2}{*}{$\begin{array}{l}\text { Days } \\
\text { (no.) }\end{array}$} & \multicolumn{2}{|c|}{ Days with attack } & \\
\hline & & & (no.) & $(\%)$ & & (no.) & $(\%)$ & \\
\hline Migraine & $\begin{array}{l}\text { (a) } \\
\text { (b) } \\
\text { (c) }\end{array}$ & $\begin{array}{l}222 \\
238 \\
238\end{array}$ & $\begin{array}{l}21 \\
22 \\
22\end{array}$ & $\begin{array}{l}9 \cdot 5 \\
9 \cdot 2 \\
9 \cdot 2\end{array}$ & $\begin{array}{l}958 \\
958 \\
985\end{array}$ & $\begin{array}{l}51 \\
51 \\
33\end{array}$ & $\begin{array}{l}5 \cdot 3 \\
5 \cdot 3 \\
3 \cdot 4\end{array}$ & $\begin{array}{l}\mathbf{P}<0.05 \\
\mathbf{P}<0.05 \\
\mathrm{P}<0.01\end{array}$ \\
\hline Non-migrainous headache & $\begin{array}{l}\text { (a) } \\
\text { (b) } \\
\text { (c) }\end{array}$ & $\begin{array}{l}82 \\
86 \\
86\end{array}$ & $\begin{array}{l}11 \\
10 \\
10\end{array}$ & $\begin{array}{l}13.4 \\
11.6 \\
11.6\end{array}$ & $\begin{array}{l}320 \\
320 \\
316\end{array}$ & $\begin{array}{l}15 \\
15 \\
16\end{array}$ & $\begin{array}{l}4 \cdot 7 \\
4 \cdot 7 \\
5 \cdot 1\end{array}$ & $\begin{array}{l}\mathbf{P}<0.01 \\
P<0.05 \\
P<0.05\end{array}$ \\
\hline
\end{tabular}

(a) Based on the first cycle only, menstrual period at beginning of cycle, but including only women for whom details of more than one cycle are available.

(b) Based on the non-menstruating portion of the first cycle and the menstrual period of the second cycle to allow for the tem poral effect (see text).

(c) Based on the second cycle only, in the same order as in (a). 
pressions and the few reported studies differ widely in methodology and results. They are mainly based on occupational groups or patients attending general practitioners. Childs and Sweetnam (1961) reported that $13.2 \%$ of female factory workers had had migraine at some time in their lives but the response to their questionnaire was low at $34 \%$. Lennox (1941) reported that $5.4 \%$ of medical students and nurses had migraine. The published prevalence of migraine from general practice varies from less than $1 \%$ (Brewis, Poskanzer, Rolland, and Miller, 1966) to over $20 \%$ (Fitz-Hugh, 1940); Fry (1955-56; 1966) gives detailed figures and records that $7.7 \%$ of females attended with migraine in a 10 year study; other figures are given by Grimes (1931), Logan and Cushion (1958), and Walker (1959). Comparisons between these various figures are difficult and profitless, as the details of the populations studied, the prevalence by age and sex, and whether the figure is a cross-sectional prevalence or one for those with migraine at any time in their life are frequently not stated. Migraine is generally considered commoner in women than men and less common in childhood and old age. These differences are relevant to any figures of prevalence.

This study gives data on the prevalence of headaches and of the various features characteristic of migraine in a representative population sample of women aged 20 to 64 years. Random samples of various subgroups defined by answers to questions were examined clinically and from their clinical interviews it is estimated that $19 \%$ of the total population had migraine attacks within the previous year. In a few additional cases women were thought to have had migraine some time ago, but not to have had an attack within the previous year. In view of the difficulty of determining the number of such cases this paper is restricted to symptoms during the previous year.

We are aware that we have estimated the prevalence without attempting to give a precise definition of migraine but we feel that a satisfactory one does not at present exist. It is a clinical diagnosis and, after a primary screening of the population, we used a clinical assessment to determine the prevalence of migraine. The figure of $19 \%$, in women aged 20 to 64 years, is considerably higher than that generally quoted. However, our findings that only $23 \%$ of those diagnosed as migraine had visited their doctor because of headaches during the previous year, and that nearly half had never consulted a doctor because of headaches, show that any data from general practice will omit a large proportion of migraine sufferers.

The subsamples of women examined clinically were selected solely on the basis of the features of their headaches (unilateral distribution, warning $\bar{z}$ nausea). It is therefore interesting that those diag? nosed as migraine have significantly more severeo headaches than those with non-migrainous headaches (Table 6) but have similar indices of psychos neurosis (Table 7). Data on the incidence of migraine and of non-migrainous headache in relation to thes time of day and day of the week and the severity and duration of the headache (Table 8) have not pre viously been reported from representative samples: of the general population. The time of onset wass? similar in migrainous and non-migrainous head-o aches with over a third starting between 8.00 hourso and noon and $40 \%$ between noon and 20.00 hours. $\frac{\bar{\rho}}{7}$ These findings are very different from those of Ostfeld (1963) who recorded most migraine headaches between 4.00 and 8.00 hours and between 20.00 hours and midnight. Walker (1959) gives the longer duration of psychogenic headache as one of $\vec{\omega}$ its distinguishing characteristics from migraine. ${ }^{\omega}$ The great majority of the non-migrainous headaches? in this study were probably 'psychogenic' and these tended to be of shorter duration with only $16 \%$ last $-\omega$ ing for more than eight hours, compared with 400 in with migraine headaches. More migraine attacts $\vec{f}$ occurred on Saturday and Sunday, which the mothers attributed to having their children at home all day. Monday had the lowest incidence of migraip. Similar distribution of attacks by the day of wegk has been given for women by Barrie, Fox, Weathera and Wilkinson (1968). The non-migrainous head- $\overrightarrow{0}$ aches showed a less consistent pattern but were a| at a minimum on Mondays.

Headache has frequently been related to menstrua-tion. Ogden (1952) found $31.1 \%$ of women gave menstruation as the cause of their headaches. Fryฏ (1966) reported that migraine was related to men-क्ष struation in $23 \%$ of female sufferers and De Wit (1950) gave the figure as $60 \%$. The situation is complicated as headaches associated with menstrua- $-\frac{3}{5}$ tion may occur at the time of ovulation, during menstruation, for a day or two after menstruation or most commonly, premenstrually (Greene, 1967). In this study both migraine and non-migrainous head-o aches were significantly commoner during menstrua- $\frac{-}{3}$ tion. The highest incidence of migraine was during the first few days of menstruation. We found migraine was significantly more frequent in the week after menstruation, a time rarely mentioned in the literature, than in the premenstrual week. The discrepancies between these findings and others? reported previously may be related to the selection of cases in previous reports, which were not based on representative population samples.

We thank Professor A. L. Cochrane, Director of the 
M.R.C. Epidemiology Unit (South Wales) for advice and encouragement and other members of staff for much assistance, especially Mr. D. Hole for help with some of the statistical analyses. The Migraine Trust gave financial support. We are grateful to the subjects in our survey for their cooperation.

\section{REFERENCES}

Ad Hoc Committee on Classification of Headache (1962). Classification of headache. J. Amer. med. Ass., 179, $717-$ 718.

Appenzeller, O., Davison, K., and Marshall, J. (1963). Reflex vasomotor abnormalities in the hands of migrainous subjects. J. Neurol. Neurosurg. Psychiat., 26, 447-450.

Armitage, P. (1966). The chi-square test for heterogeneity of proportions, after adjustment for stratification. $J$. roy. statist. Soc. B., 28, 150-163.

Barrie, M. A., Fox, W. R., Weatherall, M., and Wilkinson, M. I. P. (1968). Analysis of symptoms of patients with headaches and their response to treatment with ergot derivatives. Quart. J. Med., 37, 319-336.

Brewis, M., Poskanzer, D. C., Rolland, C., and Miller, H. (1966). Neurological disease in an English city. Acta neurol. scand., 42, Suppl. 24, 1-89.

Childs, A. J., and Sweetnam, M. T. (1961). A study of 104 cases of migraine. Brit. J. industr. Med., 18, 234-236.

De Wit, J. C. (1950). Allergy to oestrone in cases of migraine. Acta endocr. (Kbh.), 5, 173-180.

Fitz-Hugh, T. (1940). Precordial migraine: an important form of 'angina innocens'. New int. Clin., 1, 141-147.
Fry, J. (1955-56). Headache in general practice. Trans. Hunter. Soc., 14, 130-149.

Fry, J. (1966). Profiles of Disease. Livingstone: London and Edinburgh.

Gowers, W. R. (1886-1888). A Manual of Diseases of the Nervous System, 2 vols. Churchill: London.

Greene, R. (1967). Menstrual headache. Res. clin. Stud. Headache, 1, 62-73.

Grimes, E. (1931). The migraine instability. Med. J. Rec., 134, 417-422.

Lennox, W. G. (1941). Science and Seizures. Harper: New York and London.

Logan, W. P. D., and Cushion, A. A. (1958). G.R.O. Studies on Medical Population Subjects, No. 14. H.M.S.O.: London.

Ogden, H. D. (1952). Headache studies, statistical data. 1. Procedure and sample distribution. J. Allergy, 23, 58-75.

Ostfeld, A. M. (1963). The natural history and epidemiology of migraine and muscle contraction headache. Neurology (Minneap.), 13, (Part 2), 11-15.

Rawnsley, K. (1966). Congruence of independent measures of psychiatric morbidity. J. psychosom. Res., 10, 84-93.

Walker, C. H. (1959). Migraine and its relationship to hypertension. Brit. med. J., 2, 1430-1433.

Walshe, F. M. R. (1969). The enigma of migraine. Hemicrania, 1, 5-8.

Waters, W. E. (1970). Community studies of the prevalence of headache. Headache, 9, 178-186.

Wolff, H. G. (1963). Headache and Other Head Pain. Oxford University Press: New York.

World Federation of Neurology's Research Group on Migraine and Headache (1969). Migraine. Hemicrania, 1, 3-4. 